\title{
Perilaku Pencarian Informasi dan Literasi Kesehatan Digital Mahasiswa Universitas Terbuka yang Terpapar Covid-19
}

\begin{abstract}
Article Info
Article history:

Received

September $9^{\text {th }}, 2021$

Revised

November $30^{\text {th }}, 2021$

Accepted

December $4^{\text {th }}, 2021$

Published

January $1^{\text {st }}, 2022$

Abstract

Digital communication technology plays an important role in succeeding the message of the importance of government health communication and public health authorities during the COVID-19 pandemic. Nowadays both the Internet, social media and social networks have become an important source of health-related information about COVID-19 and the development of both the latest information, prevention and if exposed to what to do during isolation or communicating with local COVID-19 task force officers and the surrounding community. In addition, information related to COVID-19 is spreading faster than the coronavirus itself, which interferes with communication efforts related to government health, especially hoax and misguided news. Therefore, digital health literacy is the main competency to make the COVID-19 web-based information and service environment better and prevent misinformation received by the community. This paper tries to review the digital information literacy obtained by Open University students during exposure to covid-19, on whether there are obstacles received by UT students, what information they are looking for, how the search pattern of information and access to information used, and how the student can still attend lectures at the Open University both through webinar tutorials, online tutorials and UAS Take Home Exam despite exposure to covid-19.
\end{abstract}

\author{
Yasir Riady ${ }^{1}$ \\ ${ }^{1}$ Universitas Terbuka, Indonesia \\ e-mail: yasir@ecampus.ut.ac.id \\ donesia
}

Keywords: digital health literacy; resources; universitas terbuka students

\begin{abstract}
Abstrak
Teknologi komunikasi digital memainkan peran penting dalam mensukseskan pesan pentingnya komunikasi kesehatan pemerintah dan otoritas kesehatan masyarakat selama pandemi COVID-19. Saat ini baik Internet, sosial media dan sosial network telah menjadi sumber penting informasi terkait kesehatan tentang COVID-19 dan perkembangannya baik informasi terkini, pencegahan dan jika terpapar apa yang harus dilakukan selama isolasi atau pun berkomunikasi dengan petugas satgas COVID-19. Selain itu, informasi terkait COVID-19 menyebar lebih cepat dari virus corona itu sendiri yang mengganggu upaya komunikasi terkait kesehatan pemerintah khususnya berita hoaks. Oleh karena itu, literasi kesehatan digital merupakan kompetensi utama untuk membuat lingkungan informasi dan layanan berbasis web COVID-19 lebih baik dan mencegah misinformasi yang diterima oleh masyarakat. Tulisan ini mencoba mengulas literasi informasi digital yang didapatkan oleh mahasiswa Universitas Terbuka, apakah ada kendala yang diterima oleh mahasiswa UT, informasi apa yang mereka cari, bagaimana pola pencarian inforamasinya dan akses informasi yang digunakan, serta bagaimana mahasiswa tersebut tetap bisa mengikuti perkuliahan di Universitas Terbuka baik melalui tutorial webinar, tutorial online, dan UAS Take Home Exam meskipun terpapar covid-19.
\end{abstract}

Kata Kunci: literasi kesehatan digital; sumber informasi; mahasiswa universitas terbuka 


\section{PENDAHULUAN}

Sebagai salah satu perguruan tinggi terbuka dan jarak jauh, Universitas Terbuka hadir untuk memberikan akses pendidikan tinggi ke seluruh masyarakat Indonesia tanpa kecuali. Hal ini juga tertuang pada visi dan misi Universitas Terbuka untuk bisa memberikan layanan seluas-luasnya. Namun, sejak ada pandemi covid-19, seluruh layanan menjadi terbatas, tatap muka ditiadakan seiring dengan himbauan dan peraturan baik Presiden, Gubernur, hingga Walikota agar mengurangi penyebaran virus covid-19.

Sejak saat penetapan darurat Covid-19, virus ini melanjutkan darurat kesehatan masyarakat yang menjadi perhatian internasional. Virus COVID-19 terus menyebar ke seluruh dunia. Saat ini jutaan orang terdampak dan ratusan ribu telah meninggal akibat virus corona di seluruh dunia, bahkan di Indonesia saat ini masih memasuki gelombang kedua setelah adanya libur panjang Lebaran.

Dampak virus telah diberlakukan dan sangat terasa pada berbagai sektor, seperti pendidikan, ekonomi, dan pariwisata yang mengarah pada krisis sosial, politik, dan ekonomi. Khusus pada pendidikan, perilaku dan kebiasaan yang sebelumnya pada masa normal mejadi daring. Pada pelaksanaannya, ada banyak sekali permasalahan teknis, kuota, kebiasaan, dan fasilitas yang menjadi kendala sehingga mahasiswa lambat mendapatkan informasi dan ketika terpapar perlu mencari informasi valid yang bisa membantu mahasiswa mendapatkan edukasi dini terkait apa yang harus dilakukan selama terpapar Covid-19.

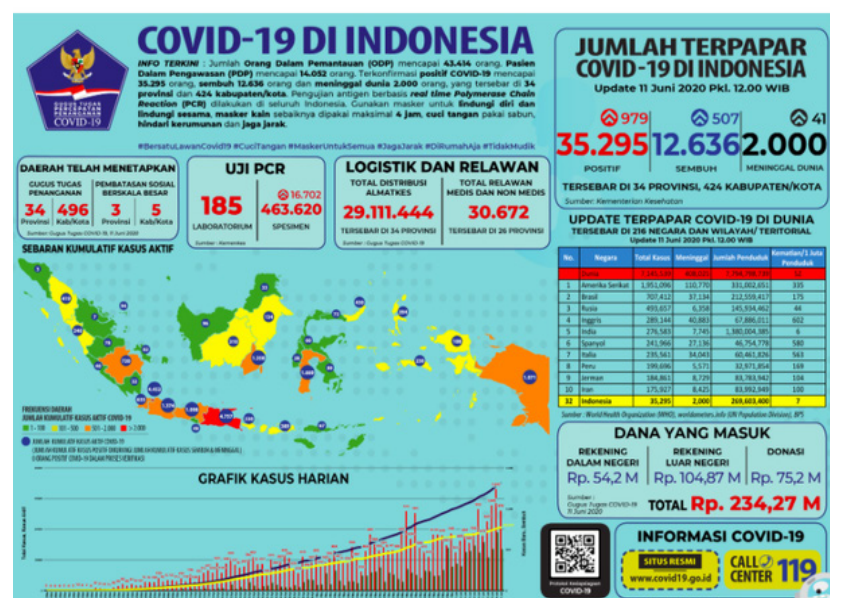

Gambar 1. Infogratis Covid-19 di bulan Juni 2020 (kompas.com)

Berdasarkan data dari Gugus Tugas Percepatan Penanganan Coronavirus Disease 2019, pada gelombang Covid-19 yang kedua di bulan Juli, jumlah masyarakat Indonesia yang terpapar cukup banyak, mengingat penyebaran virus covid-19 ini merupakan varian baru yang sangat cepat menyebar, sehingga pemerintah melaksanakan PPKM Darurat.

Grafik kasus harian pada gelombang pertama dan kedua mendeskripsikan angka yang cukup tinggi, khususnya pada gelombang kedua, Universitas Terbuka salah satu pendidikan terbuka dan jarak jauh yang sangat diharapkan bisa membantu masyarakat Indonesia agar mereka bisa melanjutkan studinya di tengah pandemi ini, harapannya dengan sistem daring, UT dapat memfasilitasi seluruh masyarakat Indonesia untuk bisa belajar dari rumah tanpa harus datang ke kampus khususnya memasuki PPKM Darurat.

Berdasarkan penjelasan di atas, penelitian ini ingin mencari dan melihat perilaku pencarian informasi oleh mahasiswa Universitas Terbuka yang positif terpapar covid-19 ketika dalam pembelajaran di Universitas Terbuka. Melalui penelitian ini bisa terlihat model apa yang digunakan oleh mahasiswa berkebutuhan khusus dan bisa dijadikan salah satu masukan dan juga saran yang perlu dilakukan oleh Universitas Terbuka untuk bisa memfasilitasi mahasiswa berkebutuhan khusus agar mereka bisa mendapatkan pelayanan pendidikan secara maksimal tanpa ada diskriminasi.

\section{Perilaku Pencarian Informasi}

Perilaku adalah setiap tindakan yang digunakan sebagai alat atau cara agar dapat mencapai suatu tujuan sehingga kebutuhan terpenuhi atau suatu kehendak terpuaskan (Ortlieb, 2014), sedangkan perilaku pencarian informasi merupakan perilaku seseorang yang selalu terus bergerak berdasarkan lintas ruang dan waktu, mencari informasi untuk menjawab segala tantangan yang dihadapi, menentukan fakta, memecahkan masalah menjawab pertanyaan dan memahami suatu masalah. Selain itu, Krikelas mendefinisikan perilaku pencarian informasi sebagai kegiatan dalam mengidentifikasikan pesan untuk memuaskan kebutuhan informasi yang dirasakan (Wilson, 1999).

Perilaku pencarian informasi berawal dari adanya kebutuhan seseorang terhadap informasi. Pada saat membutuhkan informasi untuk memenuhi kebutuhan tertentu peneliti dihadapkan pada situasi problematik. Situasi ini muncul akibat adanya kesenjangan (anomalous) antara keadaan pengetahuan yang ada di dalam dirinya dengan kenyataan kebutuhan informasi yang diperlukannya, kesenjangan ini akhirnya melahirkan perilaku 
tertentu dalam proses pencarian informasi yang oleh Belkin dinyatakan sebagai situasi problematik akibat adanya kondisi anomalous state of knowledge dari si pencari informasi (Kuhlthau, 2008).

Dalam model umum komunikasi manusia, khususnya untuk fase pencarian informasi dalam sistem informasi ilmu pengetahuan, dapat dilihat hubungan antara kebutuhan informasi dengan pencarian dan pertukaran informasi serta pemanfaatan informasi pada Gambar 2.

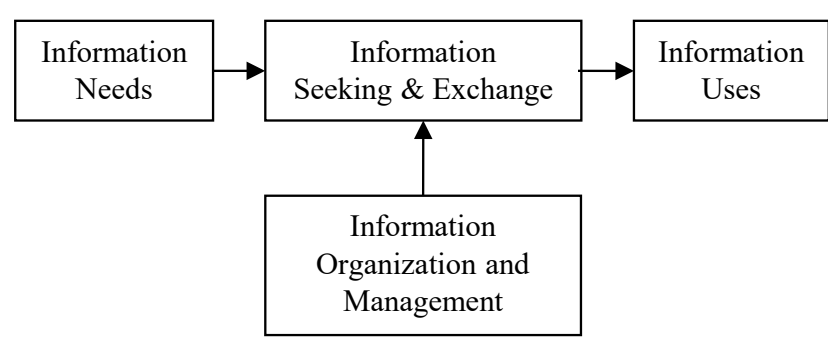

Gambar 2. Phases in the Scientific Information System

(Sumber: Katz, 2013).

Perilaku pencarian informasi mempunyai beberapa karakteristik atau ciri tertentu yang berbeda dengan karakteristik perilaku bidang lain. Karakteristik perilaku pencarian informasi dalam hal ini dimaksudkan untuk memberikan gambaran, tentang perilaku pencarian informasi di perpustakaan atau unit informasi lainnya. Menurut (Davidson, 2007), beberapa ciri yang didefinisikan sebagai kategori pencarian informasi peneliti adalah

1. Segala bentuk aktivitas peneliti yang berhubungan dengan sejawat (teman) maupun atasan atau yang lebih pakar

2. Segala bentuk aktivitas yang berkaitan dengan unit informasi, baik secara formal maupun informal

3. Segala kegiatan baik yang nampak maupun yang tidak nampak yang berkaitan dengan pencarian informasi

4. Pilihan bentuk informasi yang berkaitan dengan pemanfaatan sumber-sumber informasi

5. Penggunaan alat bantu

\section{METODE}

Mahasiswa yang menjadi informan dalam penelitian ini berjumlah 5 orang (AA, AK, CC, DB dan SM). Mereka adalah mahasiswa yang sedang menempuh studinya di Universitas Terbuka dan terpapar covid-19 ketika perkuliahan sedang berlangsung, ada yang bergejala, isolasi mandiri, bahkan di rawat di rumah sakit. Saat penelitian berlangsung, informan telah menyelesaikan beberapa semester, minimal 2 semester. Penelitian ini bersifat kualitatif dengan mencari, mendalami, serta menganalisis mahasiswa Universits Terbuka yang terpapar Covid-19 dan sedang melanjutkan studi di Universitas Terbuka.

\section{HASIL DAN PEMBAHASAN}

Pada umumnya mahasiswa memilih melanjutkan studinya di Universitas Terbuka karena lebih fleksibel tidak menuntut adanya pertemuan seperti di universitas tatap muka atau memiliki kesulitan dalam melakukan kegiatan akademik. Berdasarkan wawancara mendalam yang telah dilakukan. Alasan mahasiswa memilih jurusan di Universitas Terbuka mereka sangatlah beragam, beberapa di antaranya ada yang mengambil program Studi Sastra Inggris, Komunikasi, PGSD/PAUD, dan manajemen karena melihat minat serta keinginan yang ingin dilakukan dan juga karena profesi yang digeluti saat ini.

Memasuki pandemi, dalam pelaksanaan perkuliahan, ketika memasuki semester 2020.1, perkuliahan tatap muka ditiadakan dan digantikan dengan perkuliahan melalui tuweb atau tutorial web. Selain itu, layanan belajar terkait covid-19 ada berupa tugas mata kuliah dan juga layanan online lainnya. Informasi terkait perubahan layanan selama COVID-19 ini diinformasikan oleh Universitas Terbuka melalui akun resmi dan media yang dimiliki.

Secara umum ada mahasiswa yang mendapatkan informasi terkait perubahan skema layanan semasa pandemi Covid-19. Akan tetapi, ada juga mahasiswa yang tidak mendapatkan informasi tersebut karena beberapa alasan kesibukan dan kekhawatiran pada suasan yang terjadi dan juga pada mahasiswa yang terpapar sehingga tidak bisa mengikuti kegiatan perkuliahan dengan baik, tetapi ada beberapa informasi yang didapatkan oleh mahasiswa ketika melakukan kegiatan akademik di UT.

Berdasarkan data jajak pendapat tahun 2020 oleh litbang kompas di atas, sumber informasi utama yang didapatkan terkait COVID-19 adalah televisi sebanyak $21,7 \%$. Setelah itu, dilanjutkan dengan keluarga inti sekitar 20\% kemudian teman, tetangga, lingkungan, dan pemerintah. Hal ini sama dengan informasi yang diberikan oleh mahasiswa UT yang terpapar covid-19, selama melakukan isolasi mandiri, mereka mendapatkan berita awal melalui televisi, kemudian keluarga dan lingkungan juga memberikan update informasi dan pertanyaan terkait kondisi 
mereka. Selain itu, mahasiswa UT yang terpapar juga mencari tahu penyebab dan penyembuhannya melalui sosial media yang mereka gunakan.

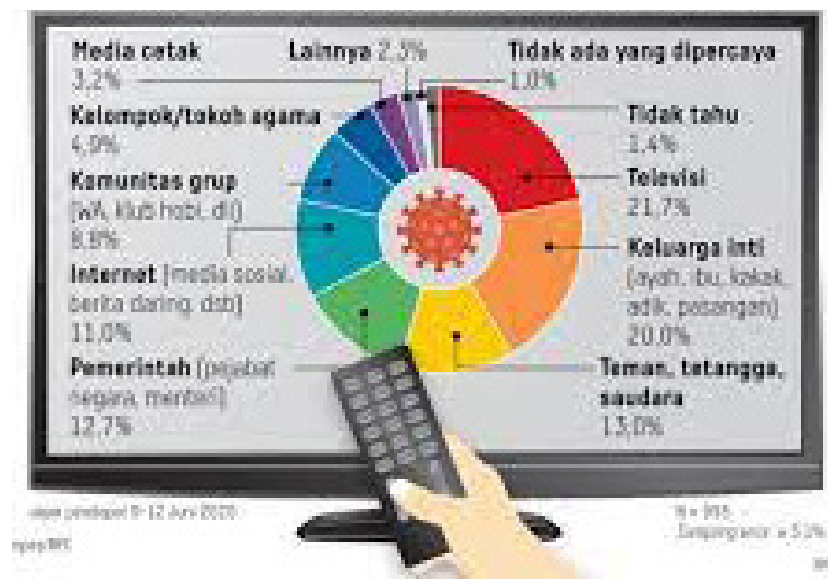

Gambar 3. Jajak pendapat juni 2020 litbang Kompas

Pada informan yang telah diwawancarai, beberapa di antara mereka pernah mengikuti perkuliahan sebelum pandemi dan ketika pandemi berlangsung, tetapi ada juga yang baru pertama kali melanjutkan studinya di Universitas Terbuka setelah berhenti beberapa waktu dan ketika pandemi berlangsung melanjutkan studinya. Secara keseluruhan alasan mahasiswa melanjutkan studi di Universitas Terbuka karena keinginan untuk menambah wawasan, ilmu hingga ingin seperti mahasiswa lain pada umumnya.

Informan AA menyatakan bahwa Universitas Terbuka sangat fleksibel sehingga tidak menggantungkan aktivitas lain khususnya selama pandemi Covid-19 ini karena informan AA juga bekerja pada bidang swasta dan terkadang medapatkan kesempatan bekerja di rumah. Selain itu, informan SM lebih ingin mengembangkan ilmu dan kariernya setelah bisa lulus dari Universitas Terbuka dan tidak terganggu waktu dan lebih aman karena tidak perlu keluar rumah. Informai AK lebih ingin bisa mendapatkan informasi yang lebih serta pengakuan yang lebih tinggi juga di masyarakat serta lebih nyaman karena seluruh kegiatannya dalam bentuk online.

\section{Melihat Fenomena Saat Ini}

Salah satu keinginan dan alasan untuk melanjutkan studi di UT selama pandemi COVID-19 ini adalah karena ingin melanjutkan studi, tetapi bisa dilakukan secara online, seperti yang diungkapkan oleh informan AA yang mengikuti perkuliahan di UT selama pandemi dan ketika terpapar tidak mendapatkan kesulian selama mengerjakan tugas di tutorial online. Pada pelaksanaannya, AA sudah memiliki dasar informasi yang cukup terkait Covid-19 karena aktivitas sehari-hari keluar rumah sehingga ia terpapar Covid-19. Hal tersebut tidak menjadi halangan bagi informan AA dalam melanjutkan studinya di Universitas Terbuka. Informan SM lebih melihat trend yang ada serta berhubungan dengan aktivitas yang dilakukan hingga saat ini dan juga selama pandemi semua kegiatan menjadi online.

Informan yang lain melihat fenomena ini dan khawatir, terlebih beberapa keluarga intinya terpapar positif sehingga mahasiswa ada yang mencoba berusaha agar tetap bisa melakukan aktivitasnya tanpa terganggu meskipun terpapar COVID-19. Berdasarkan pelaksanaan semester 2020.1 dan 2020.2, ada juga mahasiswa yang memberikan surat untuk dispensasi pelaksanaan SUO Sistem Ujian Online TAP (Tugas Akhir Program) untuk diundur atau dijadwal ulang hingga mahasiswa benar-benar sudah sembuh dan pulih.

\section{Alasan Mencari Informasi COVID-19}

Berdasarkan informasi wawancara dari informan mahasiswa UT yang terpapar Covid-19, alasan utama ketika mereka mendapatkan diagnosis positif COVID-19 sebagain besar adalah mencari informasi terkait gejala dan pengobatan. Selain itu, informasi dari mahasiswa UT mempelajari tracing kasus tersebut, penularan, dan pencegahan dan metode yang digunakan pada kasus Covid-19 ini. Pada perilaku pencarian informasi ini pertama mereka lakukan ketika mereka merasakan gejala yang sama atau setelah diberikan informasi oleh kerabat yang sudah positif dan melakukan interaksi sebelumnya. Hal ini menjadikan perilaku kebutuhan untuk starting informasi awalnya sudah tinggi dan kebutuhan akan banyak sumber informasi sangat dominan.

Kebutuhan informasi oleh penyedia layanan kesehatan meningkat dengan munculnya pandemi COVID-19 di seluruh dunia. Penyedia layanan perawatan membutuhkan berbagai jenis informasi tentang diagnosis, perawatan, dan prosedur medis yang dianggap membantu pengendalian pandemi COVID-19. Saluran media sosial dibedakan sebagai sumber informasi terpenting tentang penyakit coronavirus dan sumber informasi paling signifikan lainnya adalah artikel, jurnal, penelitian maupun sumber pada perpustakaan digital dan repositori.

Selain sumber informasi sebelumnya, televisi dilaporkan sebagai salah satu sumber utama informasi 
Yasir Riady, Perilaku Pencarian Informasi dan Literasi Kesehatan Digital Mahasiswa Universitas Terbuka...

tentang covid-19, karena selain terkini, siaran di televisi pada berita dan iklan bisa menjangkau seluruh lapisan masyarakat baik di kota maupun daerah. Munculnya pandemi COVID-19 telah meningkatkan kebutuhan penyedia layanan kesehatan akan informasi dan perilaku mencari informasi secara drastis dan menyeluruh, namun yang patut diwaspadai adalah banyaknya beredar informasi hoaks dan menyesatkan terkait COVID-19, vaksin, dan obat yang digunakan.

\section{Literasi Informasi dan Kepercayaan Sumber Informasi}

Salah satu permasalahan yang muncul ketika pandemi adalah beragam informasi yang beredar. Saat ini ada banyak sumber-sumber berita yang beredar baik di sosial media dan sosial network, tidak terkecuali informasi bagi mahasiswa di Universitas Terbuka. Informasi yang diterima oleh mahasiswa terkait covid dan layanan akademik dan perubahannya di Universitas Terbuka baik pada TMK atau Tugas Mata Kuliah dan UAS THE atau Take Home Exam mempengaruhi perlaku pencarian informasi oleh mahasiswa yang sedang melaksanakan kegiatan dan maupun mahasiswa yang terpapar.

Hasil penelitian ini mengidentifikasi beberapa sumber media penyedia layanan kesehatan yang digunakanoleh mahasiswaUT, seperti PeduliLindungi, aplikasi kesehatan (Halodoc atau Alodokter), beragam aplikasi lainnya, serta berita untuk mencari informasi. Hasil wawancara mendalam juga memberikan arahan bagi para pengambil kebijakan dan kementerian untuk memilih sumber informasi yang tepat untuk menyebarluaskan informasi terkait pandemi, seperti COVID-19. Hampir semua mahasiswa UT yang terpapar Covid-19 mendapatkan masukan, saran, dan informasi terkait penanggulangan COVID-19 dari keluarga terdekat, lingkungan RT dan RW, hingga petugas medis.

Menurut hasil informasi dari mahasiswa, kredibilitas sumber informasi yang didapatkan sangat bervariasi. Para mahasiswa menemukan situs web dari Kementerian Kesehatan, pemerintah kota, dan data dari sumber yang sangat tepercaya. Akan tetapi, ada beberapa website dan sumber informasi yang kurang update dan tidak akurat. Alasan yang mungkin untuk memiliki kepercayaan tinggi pada informasi yang disebarluaskan bisa disebabkan oleh informasi yang salah tentang COVID-19 dari sumber media sosial. Informasi sangat cepat dan terkadang agak sulit membedakan mana informasi yang valid dan tidak. Sama halnya dalam pelaksanakan kegiatan belajar di UT, mahasiswa mendapatkan sumber informasi awal dari sosial media UT, website, pengelola kelompok belajar (pokjar), dan juga rekan sekelas mahasiswanya.

\section{SIMPULAN}

Berdasarkan data analisis yang sudah dilakukan serta wawancara mendalam dengan sumber informan, ada banyak media yang digunakan oleh informan, yaitu mahasiswa UT ketika terpapar Covid-19. Selain itu, informasi yang dibutuhkan oleh mahasiswa sangat erat kaitannya dengan topik kebutuhan terkait apa yang mereka alami saat itu, seperti informasi pencegahan, pengobatan, dan update terkini selama pandemi. Mereka juga tetap menjalankan studi atau tugas mereka di Universitas Terbuka, baik pada kegiatan tutoriab web, turorial online, maupun tugas mata kuliah.

Mahasiswa juga sangat membutuhkan beragam referensi untuk pengetahuan dan kebutuhan mereka dalam mendapatkan literasi informasi terkait kesehatan. Pada umumnya sebagain besar mengatakan televisi, kemudian keluarga inti, hingga lingkungan. Selain itu, sumber informasi yang paling populer dan sering digunakan oleh mahasiswa adalah sosial media dan sosial network karena berisi informasi-informasi yang terkini, relevan, dan akses yang mudah serta memberikan informasi yang rinci dan mendasar. Sayangnya banyak informasi hoaks dan tidak valid yang beredar pada sosial media sehingga mahasiswa harus memvalidasi dan memastikan kebenaran informasi yang beredar.

\section{DAFTAR PUSTAKA}

Barrett. 2005. The information-seeking habits of graduate student researchers in the humanities. Journal of Academic Librarianship, 31(4), 324-331.

Davidson, J. E. 2007. An overview of international research into the library and information needs of visually impaired people. Library Trends 55(4),785-796

Halloway, S. (2001). Experience of higher education from the perspective of disabled students. Disability and Society, 16 (4), 597-615.

Katz, I. (2013). Testing information literacy in digital environments: ETS skills assessmentv Information Technology and Libraries, 26(3), 3-12.

Kuhlthau, C.C., HeinstrÖm, J. \& Todd, R.J. 2008. The 'information search process' revisited: is the model still useful?” Information Research, 13(4), 355. [Available at http://InformationR.net/ir/13-4/ paper355.html]

Ortlieb, E. (2014). Attraction theory, practice and evaluation. Literacy Research 4(3), 20-30.

Ray, K. \& Day, J. 2013. Student's attitudes towards electronic information sources. Information Research, 4(2). 
Saumure, K. \& Given, L.M. (2004). Digitally enhanced - An examination of the informationbehaviours of visually challenged Post- Secondary students. Canadian Journal ofInformation and Library Science, 28 (2), 25-42.

Taylor, A. 2012, A study of the information search behaviour of the millennial generation. Information Research, 7(1). Retrieved March, 2014 available at http: //www. informationr. net/ ir/17-1/paper 508 . html

Urquhart \& Rowley, J. 2007. Understanding student information behaviour in relation to electronic servi-ces: lessons from longitudinal monitoring and eva-luation. Journal of the American Society for Information Science and Technology, 58(8), 11881197

Wilson, T.D. 1999. Models of information behaviour research. Journal of Documentation, 55(3), 249-270. Website: http://www.informationr.net/tdw/publ/ papers/1999 jdoc.html.

Wilson T.D., 2005. "Evaluation in information behaviour modeling: Wilson's model." In Theories of information behavior, K. E. Fisher, S. Ederle and L. McKenchnie eds. Medford, NJ: Information today, pp. 3136, .11. T. D. 